\title{
Hiding in Plain Sight - Au Pairs in Australia
}

\section{Laurie Berg}

Appears in Rosie Cox (ed), Au Pairs' Lives in Global Context: Sisters or Servants? (Palgrave Macmillan, 2015) reproduced with permission of Palgrave Macmillan. This extract is taken from the author's original manuscript and has not been edited. The definitive, published, version of record is available here: http://www.palgrave.com/page/detail/au-pairs-lives-in-globalcontext-rosie-cox/?K=9781137377470.

\section{Introduction}

The use of 'au pairs' in Australia is thought to have dramatically increased in recent years, according to anecdotal reports, marking a significant reversal of historical trends. Au pairs in Australia are covered by no government regulatory scheme: there is no dedicated visa, no official guidelines governing the terms of placements, nor any official definition of au pairs. The term 'au pairs' in Australia refers loosely to young people from foreign countries who care for children in a family in exchange for board and a stipend (CAPAA, 2014, p 4).

Au pairs appear generally to enter Australia on Working Holiday visas (WHVs), which were designed to promote 'cultural exchange' of up to one year for young people from affluent countries with which Australia fostered a reciprocal relationship. In 2013, au pair agencies estimated that they administered roughly 2,000 placements (Miletic, 2014), and that demand for au pairs had doubled in three years and was expected to double again in next 18 months (Marriner, 2013). However, since a significant amount of au pair work takes place informally, bypassing brokers, the actual size, institutional distribution, and personal characteristics of the industry's participants are unknown. Living and working conditions of au pairs appear to be highly variable: one au pair agency recommends a minimum of AUD150 (US\$139.00) and 20-25 working hours a week (Marriner, 2013), whereas another recommends AUD200-250 (US\$ 185232.00) for 20-30 working hours a week (Collins, 2013).

Specific social attitudes to work, care, migration and gender in Australia may explain both the absence of any official au pair scheme and the recent surge in demand for au pairs. Paying for domestic work has not historically featured prominently among middle-class Australians, in part because caring in Australia has traditionally been considered an unpaid family role (Hugo, 2009, p 192). As greater numbers of women have entered the paid workforce in recent decades, state fiscal policies have favoured institutional group-based daycare for children over household-based childcare arrangements. Nor have migrant domestic workers been prevalent, due to Australia's deep historical aversion to temporary or low-waged labour migration in general. However, cultural views about the appropriateness of both paid domestic work and temporary migrant labour in Australia may be transforming, along with various state policy 
changes influencing both demand for and supply of flexible care labour. Growing income inequality is making it increasingly easy for the wealthy to pay for others' labour. Significant labour market deregulation in the 1990s caused Australia's once centralised and uniform labour protections and social benefits to become increasingly piecemeal and saw rapid liberalisation of temporary labour migration.

By facilitating au pairing implicitly through a visa scheme designed for 'cultural exchange', the growing demand for cheap and highly flexible childcare can be met without any serious challenge to the prevailing ideology that housework and home-based care are not work. Indeed, achieving au pairing through the working holiday program serves to assiduously avoid the unegalitarian, colonialist or racialised overtones of a foreign labour scheme in Australia. The differentiation of WHV visa-holders from stereotypical 'guest workers' is reinforced through various eligibility requirements of the WHV such as applicants' youth, national background in industrialised countries and capacity to finance travels. Au pairing, therefore, provides a form of paid domestic labour while maintaining ongoing restrictions on low-waged labour migration.

This chapter examines the rights and vulnerabilities of au pairs in Australia which are produced through the immigration rules which determine the terms of their stay. It argues that the WHV rules in fact place au pairs in a double bind: a highly contradictory regulatory framework excludes au pairs from employment protections yet treats au pairs as workers within immigration regulations. This leaves au pairs at acute risk of falling foul of strict immigration controls. Rosie Cox has likened au pairs in Britain to unauthorised workers, to a degree, because of the lack of official regulation there (Cox, 2012, p 41). In Australia, au pairs in fact run the serious risk of actually becoming unauthorised workers, and being rendered susceptible to detention and removal from Australia, because ambiguities surround whether their tenure with families is classified as work outside of the sanctioned limits of their visas. Meanwhile, families who host au pairs are immune from prosecution for unlawfully employing au pairs who are unauthorised migrant workers (Australia's employer sanctions laws include a carve-out for domestic labour). This toxic combination produces serious precariousness for au pairs, whilst providing families with risk-free access to cheap childcare labour. These entrenched legal uncertainties meet Australian families' competing desires: to attract low-waged migrant labour while disavowing a guestworker scheme.

This chapter explores some of the silences and ambiguities surrounding au pair work in Australia through a close reading of the WHV path which facilitates it. It commences with a brief background on the cultural assumptions in Australia about housework, gender and migration. It then turns to a discussion of how au pairing is facilitated by the WHV and how this breeds insecurity in au pairs' living and working conditions. The chapter then explores how the recent growth in au pairing in Australia has come to manage a deep ambivalence about foreign workers and childcare in Australia. It concludes by appraising legal reforms which have been sought by au pair agencies to standardise au paring in Australia. While an official 
programme and a dedicated visa may well ameliorate the precarious situation of au pairs within the current WHV scheme, a range of safeguards are necessary to support the labour rights of au pairs.

\section{Housework, Gender and Migration in Australia}

Australia stands apart from many states in Europe and North America in that it lacks a formal au pair scheme or dedicated visa pathways for au pairs. Baxter (2005, p 380) has argued that the virtual nonexistence of live-in domestic workers in Australian households is due to a gendered division of labour that defines housework and children as non-work, and women as the primary carers of husbands and children. However, in this section I argue that there are also racialised reasons for the shape of Australia's household-based care industry which is so unlike countries where cheap immigrant labour is plentiful. Australian immigration policies have discouraged the development of a less-regulated, low-status migrant service class, despite pressure from employers in some cases (Hugo, 2009, p 189), although there is evidence that this approach has been slowly changing.

Higman (2002) has detailed the historical contours of domestic service in Australia. Australia's small domestic services industry has not historically relied on a transnational workforce. The White Australia policy, in place between Federation in 1901 and the 1960s, all but prevented first non-British and later non-European migration altogether. The use of white household servants declined rapidly after World War I (Callister, 2009, p 3) as domestic labour came to be defined no longer as work but rather an integral part of women's proper role as mothers and wives. As Baxter notes (2005, p 383), the dominant model of Australia as a 'male breadwinner state' (reaching its peak in the 1950s and 1960s) set men's wages according to a presumption of a wife and child dependents and relegated women to full-time unpaid roles as mothers and housewives.

The labour market participation of women grew dramatically through the 1970s and 1980s, but chiefly in part-time positions, in which Australia has one of the highest concentrations of women in the world (Summers, 2003, p 161). Policies ostensibly designed to address women's dual burden of paid and unpaid work have primarily focused on strategies that help women to combine these competing responsibilities, for instance through governmental moves to expand and subsidise institutional pre-school childcare places in the 1980s (Bittman, 1995). While household expenditure on institutional childcare substantially increased by the 1990s (Bittman, 1999, p 262), there is evidence of only a slight increase in expenditure on home-based childcare and no evidence of a trend toward live-in childcare workers (Baxter, 2005).

The ongoing reluctance of many Australian families to pay for domestic labour suggests a complex interplay of cultural norms about femininity and economic factors. One study points to limited trust in informal rather than formal childcare arrangements and specific cultural 
views about the inappropriateness of using paid domestic workers (Baxter, 2005, p 21). Even as the use of paid household labour began to rise in the 1990s, 'the new rich sometimes felt that employing domestic servants was embarrassing' (Higman, 2002, p 4). But Baxter (2005) has also located a significant impediment to employing domestic workers in its unaffordability. The preference for group daycare over household-based arrangements has been strongly influenced by tax rebates for using an approved childcare centre covering roughly half its cost (families can claim back roughly AUD145 a week) while a much smaller tax rebate is available for families who hire approved nannies or other home-based workers (around AUD32 a week). These policies have kept demand for domestic workers low and for migrants undertaking more informalised domestic work lower still.

Another crucial factor for the infrequency of employing domestic workers relates to labour supply. Internationally, lower-skilled migrant women tend to be over-represented amongst domestic workers. However, Australian immigration policies have strictly limited the extent to which foreign workers are available to do this work by overwhelmingly favouring higher skilled permanent migrants. This reflects historical resistance to using temporary workers to meet labour shortages at all, perceiving negative experiences associated with such migration in Europe in the 1950s and 1960s (Hugo, 2009, p 199). Only in the 1990s have we seen dramatic turns toward temporary labour migration and these entrants have tended to be highly skilled (Tan and Lester, 2012, p 359). Childcare-related occupations were recently included on the skilled immigration list for permanent residence but only for managerial roles (Hugo, 2009). Australia has no visa pathway through which private households may recruit domestic labour from abroad, such as Canada's live-in caregiver scheme, nor a formal au pair scheme, such as in North America or northern Europe.

Furthermore, Australia's geographic isolation and strong immigration compliance framework have severely limited the presence of unauthorised migrants (who may be available to do cashbased informal care work) by global standards (Howells, 2011, p 24). Harsh entry criteria deny even visitor visas to those judged to be at risk of overstaying (on the basis of their nationality, socio-economic status or familial relationship with an Australian resident) and those who enter Australia without visa authorisation are invariably detected and detained.

However, the reluctance around employing household services now seems to be dissipating as a result of a complex interaction of demand and supply. More 'family-friendly' policies such as the introduction of paid parental leave entitlements, possibilities for part-time and flexible work, and state-subsidised preschool have contributed to increased female employment. Growing income differentials between the richest and poorest in Australia are allowing domestic work to be contracted out. At the same time, there does not appear to be an increasing number of Australian residents willing to undertake paid domestic work, nor an appetite to include it within the current high skilled immigration program. A leading demographer has highlighted the possible future shortage of a labour force for elder care and the possible need 
for a broader base of skills, and occupations in lower-waged industries, to be reflected in Australia's immigration intake (Hugo, 2009, p 199).

Yet despite the persistence of strict entry barriers to low-waged migrant labour, certain anomalies within Australia's immigration policies in fact facilitate the presence of a significant migrant workforce relegated to low-status, part-time work at the more insecure end of the labour market. The last decade has seen the exponential growth of non-citizens entering through WHVs or as international students, who together may comprise around $9 \%$ of parttime workers (Reilly, 2012, p 185). These temporary residents are not represented to the electorate as workers, and do not conform to popular assumptions about low-waged transnational workers as poor or uneducated. Yet they are highly likely to work in Australia to financially support their stay, often in informal work. It is through these channels, rather than through a dedicated visa, that au pairs have increasingly been living in Australian households.

\section{Au Pairs as Working Holiday Makers}

In the absence of an official au pair scheme, therefore, the chief regulatory framework governing au pair placements lies in the conditions of entry and stay on au pairs' visas, predominantly the WHV. Every au pair agency consulted for this research recommends that families and au pairs use the WHV to facilitate their arrangements and, for this reason, they advise that au pair placements in Australia generally must last for no more than six months (in line with the work restrictions on this visa, as discussed below). Because the government does not require WHV visa-holders (known as Working Holiday Makers (WHMs)) to report their occupation, it is impossible to determine exactly how many work as au pairs while in Australia. However, anecdotal reports of a rapid increase of au pairs entering Australia reflect both the recent expansion of the WHM program and reports of escalating demand for domestic labour. This section provides a brief overview of the WHV before turning to the implications of its visa conditions for au pairs. As we will see, belying the 'cultural exchange' rationale of the WHM program, in fact it has clearly been instrumentalised in recent years as a temporary low-waged migrant labour program.

WHMs are allowed to enter Australia for a twelve month 'cultural exchange', permitting work that is 'incidental' to the holiday. Visa applicants must be aged 18-30 and a national of certain countries which have reciprocal relationships with Australia (overwhelmingly wealthy countries in Europe, North America, and parts of South East Asia). ${ }^{i}$ The largest source countries are currently Britain and Taiwan, followed by South Korea, Germany and France (DIAC, 2012, p 7). Unlike almost any other temporary visa in Australia, dependent children or a partner may not be incorporated on the primary WHV; instead, an au pair's partner wishing to enter Australia must apply for (and be eligible for) their own visa. 
However, strong evidence suggests that for some time the scheme's rationale has shifted from promoting tourism to a purpose-designed temporary labour market program. Technically, WHMs are permitted only to engage in work that is 'incidental' to the holiday. Indeed, a parliamentary inquiry into the scheme in the late 1990s recommended it not be 'used to solve labour market problems in Australia' (JSCM, 1997, p xvii). However, in practice, WHMs may do any kind of work provided they spend no more than six months with any one employer.ii (The limit on the permissible duration of work with a single employer was extended from three to six months in 2006.) Other policy changes suggest the visa has been used to address labour shortages in regional industries. Since 2005, visa-holders may apply for a second year-long visa if they complete at least three months 'specified work in regional Australia', including the agricultural, mining and construction industries.ii This extension is highly popular: in 2011-12 roughly one in six WHMs acquired a second visa (DIAC, 2012, p 4). These reforms were openly driven by employer interests in industries where WHMs were coming to play a key role and, unsurprisingly, au pair agencies have sought (but have not yet been granted) inclusion of au pairing in regional areas among these other preferred industries (CAPAA, 2014).

Clearly, many WHMs are in Australia to work and the scheme is designed to facilitate certain labour market effects. The Immigration Department frankly acknowledges the work motives of many WHMs. The scheme increased by almost 25\% between 2011 and 2012 (DIAC, 2012, p 7), when strong work opportunities in Australia attracted WHMs from partner countries where unemployment levels had skyrocketed following the Global Financial Crisis. Irish WHMs in particular surged from 14,790 in 2009 to 25,827 two years later (DIAC, 2012, p 12). A major government-supported research project surveying 20,000 WHMs in 2008, reported that 69\% worked during their stay and $48 \%$ said that 'work in Australia' was a principal reason for their trip (Tan, 2009, p 13). This study also demonstrates that WHM labour is overwhelmingly at the low-waged end of the labour market: the occupations of 'farm hand' and 'waiter' together accounted for $40 \%$ of respondents' jobs followed by 'cleaner' (8\%) (Tan and Lester, 2012, p 373).

Unfortunately, no research to date has shed light on the number or experiences of au pairs holding WHVs. Since au pairs are likely numbered in thousands rather than tens of thousands, figures on the prevalence of au pair work among WHMs are not discernible from the 2008 quantitative study. Nor is it known if respondents who nominated the occupation 'cleaner' were engaged in domestic or commercial cleaning work, or may have included au pairs. The general invisibility of au pairing in Australia in immigration and labour policy discussion is compounded by an almost complete dearth of critical scholarship (for a rare exception on au pairs in Australia discussed in comparative context see Yodanis and Lauer, 2005). The official silence surrounding au pairs in Australia is so thorough-going that there was not one mention of au pairing in a major parliamentary inquiry into the WHV scheme in 1997 (JSCM, 1997), nor in two major government-supported research projects into WHMs (Harding and Webster, 2001; Tan, 2009). 


\section{How Immigration Controls (and Not Labour Law) Regulate the Work of Au Pairs}

The absence of an official au pair scheme benefits au pairs in certain ways. Since WHVs may freely work in Australia, the visa does not preclude an au pair changing families or leaving au pairing altogether to find alternative work while in Australia. Consequently, au pairs in Australia are not dependent on their host families for the ongoing validity of their visa as they are in some countries.

However, in other ways the lack of official guidelines leaves au pairs in Australia in a seriously vulnerable position. This section explores how au pair placements are not clearly included within the ambit of employment laws, although, paradoxically, au pairing does appear to be treated as 'work' within the prescribed limits of the WHV. This uncertain regulatory context reproduces historical contradictions about the scope of productive labour, and specifically what counts as family and what counts as work.

Turning first to employment protections, anecdotally au pair agencies and government tax and labour inspectors seem to exclude au pairing from the categorisation of work. Like many of their counterparts around the world, au pair agencies in Australia describe recommended pay rates as 'pocket money'iv or 'living allowance'.v They generally offer little guidance to au pairs about any obligations to declare these payments as income tax. ${ }^{\mathrm{vi}}$ Whether au pairing is considered remunerated work by tax and labour inspectorates, and whether payments should satisfy minimum wage entitlements, is unclear. Australian employment laws do not generally exclude domestic work from their purview, except in two states: Western Australia and South Australia.vii Indeed, even if au pairs' 'pocket money' were not classified as wages, courts have held that there could be an employment contract in the absence of agreement as to wages. One superior court has held that a live-in caretaker and instructor at a flying club was an employee. Although he received no wages, the provision to him of rent-free accommodation was taken to satisfy the need for consideration in a binding contract (Cudgegong Soaring Pty Ltd v Harris, 1996).

However, the view that au pairs are employees or independent contractors does not appear to be reflected in the practice of the Fair Work Ombudsman (FWO), Australia's chief labour watchdog. A comprehensive study by two labour law experts on unpaid work commissioned by the FWO in 2013 did not conceptualise au pairing even as unpaid work. The report (entitled The Nature, Prevalence and Regulation of Unpaid Work Experience, Internships and Trial Periods in Australia: Experience or Exploitation?) ran to almost 400 pages without a single reference to au pairs (Stewart and Owens, 2013). It does express concerns about the prevalence of unpaid work by WHMs but in relation to backpackers doing volunteer work in the horticultural industry in the hope of qualifying for a second visa rather than au pairs working in host families' homes.

Yet, incongruously, au pairing appears to be presumed to be work for immigration purposes by the Immigration Department and au pair agencies. It will be recalled that WHVs limit visaholders to six months work with any one employer. Under the Migration Regulations, work is 
defined as 'an activity that, in Australia, normally attracts remuneration' (reg 1.03). That au pair agencies consider family stays to be work for the purpose of visa conditions, and therefore limited to six months under the WHV, is discernible from their advocacy for a novel visa dedicated exclusively to au pairs to enable au pairs to remain with their host family for a full year (discussed in more detail in the following section). The view that agencies regard au pairing as work was also suggested by one agency's submission to a senate inquiry in 1997 to the effect that it used student visas at that time so that au pairs could remain with families for more than the three months then permitted by the WHV, even though that meant that au pairs had to scrupulously ensure they did no more than 20 hours of care work or housework each week to remain compliant with the relevant student visa work restrictions (JSCM, 1996).

The Immigration Department's attitude on whether au pairing constitutes 'work' under a temporary visa is less clear. If au pairing is work, any au pair on a WHV who remains with their host family for longer than six months may have their visa cancelled (Migration Act, s 109). Upon visa cancellation, a non-citizen is required by Australian law to be mandatorily detained and removed as soon as practicable (ss 189 and 198). My research indicates that in recent years the Immigration Department has approached au pairing as work. For instance, in a pilot study on au pairs I conducted in Sydney, I interviewed a young German woman whose visa was cancelled and who was detained and removed from Australia because her au pairing was determined to contravene her visitor visa conditions prohibiting any work. Whether au pairing always constitutes work remains unresolved as a matter of law or policy. The fact that this issue has not been fully ventilated may reflect the currently small numbers of au pairs in Australia. However, the significance of this question is far from theoretical, as the experience of the young German interviewee makes clear.

It is well recognised in the international scholarship that au pairs can be susceptible to mistreatment by their host families due to their youth, lack of fluency in the local language and unfamiliarity with local laws and customs (see, eg, Anderson, 2009; Cox and Narula, 2003). However, the ambiguity about whether au pairing constitutes work in Australia creates a further significant source of vulnerability. Unlike the extremely serious consequences for an au pair who extends her family placement beyond the permitted period, no consequences whatever flow to the host family. Employers of migrants who lack permission to work may, in general, be subject to criminal or civil penalties, but employers in a 'domestic context' (s 245AG(2)) are immune from sanction. Consequently, whenever a family and au pair decide to extend the placement beyond that permitted under the WHV, the costs of detection bear down on the au pair alone.

\section{Understanding the Recent Growth in Au Pairing in Australia}

International scholarship has examined in detail how au pair schemes allow host states to manage deeply contradictory attitudes to foreign domestic workers and childcare (Isaksen, 
2010; Cox, 2012). Au pairs are paid workers who are not seen as employees (Mellini, 2007): in fact they are frequently constructed by official discourses as neither workers nor migrants but as participants in a 'cultural exchange' programme (Cox, 2007, p 22). At the same time, au pairs increase the availability of market-based childcare while minimising its cost, precisely because they are not defined as employees (Yodanis and Lauer, 2005).

Using the WHV scheme as the vehicle for outsourcing of childcare has specific cultural resonances in Australia, a country which has yet to embrace devolution of childcare to the market as fully as others. While Australians may be uncomfortable about the idea of employing a domestic worker - since they see themselves as egalitarian and opposed to labour market segmentation on the basis of class and race - 'hosting' an au pair provides a frame they find less embarrassing (cf Isaksen, 2010 for a similar situation in the Nordic countries). As discussed earlier, the WHV scheme in general permits the Australian government to de-emphasise the presence of thousands of foreign workers in Australia, while taking advantage of their labour. In the words of a representative body of au pair agencies, 'International Au Pairs present a very attractive opportunity for the Australian Government: the opportunity to grow inbound youth tourism whilst addressing a childcare shortage' (CAPAA 2014). The visa allows Australian families to view the care work in their home as an opportunity for the au pair rather than a burden, and to see themselves as benefactors rather than employers (Chuang, 2013, 287).

The eligibility criteria of the WHM scheme may go some way towards preventing the most egregious exploitation of au pairs. The WHV is only available to people from specified industrialised countries who pose very little risk of contravening immigration controls and have sufficient funds for a return airfare. Consequently, visa-holders are preselected specifically because they are less likely to be utterly dependent on an abusive host family for their livelihood. The socio-economic background of au pairs on WHVs is therefore often similar to their Australian employers. Indeed, according to a 2001 survey of the labour market impact of 1001 WHMs, WHMs are better educated, on average, than Australians (Harding and Webster, 2001, p 5-6). Employers can consequently take advantage of their 'unskilled' labour while envisaging that the au pairs and other WHMs may move into higher paid and more skilled jobs upon departure from Australia. Denying WHMs jobs with clear career progression is justified on the basis that they gain longer-term advantages through English language acquisition or gaining a foothold in the Australian labour market (Tan, 2009, p III). This avoids, at least in the popular imagination, the exploitative undertones of domestic worker migration as it exists in the United States, Canada or Europe (see, eg, Chuang, 2013; Sollund, 2010).

At the same time, a complex blend of the assumed foreignness and transience of WHMs (including au pairs) leaves them in a distinctly more precarious labour market position than young Australians. As non-citizens entitled only to temporary residence, WHMs are positioned sufficiently outside of the local Australian social structures that their labour can be instrumentalised in ways that an Australian university student's would not. In fact, there is evidence that WHMs are more likely than Australian resident workers to be subject to illegal 
labour practices: Tan and Lester's 2008 survey revealed that 36\% of WHMs were paid below the national minimum wage rate (Tan and Lester, 2012, p 368). Thus, while Australian families may seek au pairs who are viewed as class peers rather than a subordinated group to find a measure of cultural acceptability in paying for in-home child care, they may simultaneously be motivated to take advantage of precisely those axes of difference between themselves and au pairs in their effort to ensure that outsourced childcare is cheap and flexible.

Questions around au pairs' entitlements and the proper legal categorization of au pairs are gaining urgency. On gaining power in 2013, the conservative federal government expressed a commitment to establishing 'more affordable, flexible' childcare (Productivity Commission, 2013). It launched a Productivity Commission inquiry into the sector, citing 'shortage of childcare' and rising childcare costs (Miletic, 2014). This demand for care labour that responds to the 'needs of today's families and today's economy, not the five-day 9am-5pm working week of last century' (Productivity Commission 2013) itself stems from the proliferation of more insecure forms of employment. The inquiry is likely to canvas policy mechanisms which will provide cheaper care labour (in other words, available for less than the pay rates of the working women whose labour is being replaced) which is available over long and irregular hours. Among other measures, the government has raised the possibility of increasing tax rebates for home-based child care options such as nannies.

At around the same time, various au pair agencies have mobilised, establishing a peak representative body, the Cultural Au Pair Association of Australia (CAPAA), in 2012 which is advocating for standardisation of au pairing in Australia. In its submission to the Productivity Commission inquiry into the childcare sector, CAPAA has called for a dedicated visa to permit au pairs to spend up to 12 months in their family placement (CAPAA, 2014). It is pressing for this visa to be available for au pairs from countries beyond those currently eligible for a WHV (Brazilians, who are not eligible to be WHMs, are considered by CAPAA to be particularly desirable au pairs since 'culturally they're a really good fit' (Westcott, 2013)). In addition, CAPAA called for the childcare rebate for day care fees to be extended to families who host au pairs (as occurs in New Zealand) (CAPAA, 2014).

A dedicated au pair visa may well be desirable to address the precarious situation of au pairs within the current WHM scheme. Creating an official au pair programme would likely provide better regulation of pay rates and working hours, with model contracts outlining conditions of placement including hours, duties, pay, holidays, sick days and termination details, and a system of data collection for the industry including background checks for au pairs and families by government agencies.

However, any such visa must not bind au pairs to their placement through a family sponsorship mechanism. Making an au pair visa conditional on family sponsorship might serve the interests of families in retaining au pairs over extended periods of time (Anderson, 2006) but it would severely impair au pairs' ability to make alternative arrangements if they find their initial family 
placement unsuitable. Furthermore, while it would be desirable for the official guidelines to make explicit the working hours of au pairs expected under the scheme, the validity of the au pair's visa must not depend on the au pair complying with such limits. To do otherwise would doubly punish au pairs who are requested or pressured to work longer than agreed hours by rendering them vulnerable to precarious immigration status, possible detention and removal. In short, any guidelines and dedicated visa pathway established by the Australian government must safeguard the rights of au pairs.

\section{Conclusion}

The official silence around au pairs in Australia may magnify the deleterious effects of immigration controls on their rights and protections. This chapter has argued that the WHV scheme breeds precariousness in au pairs' living and working conditions as a result of ambiguities around whether au pairing is characterised as work: au pairs are excluded from employment protections yet are treated as workers within immigration regulations. They are, therefore, left at serious risk of violating strict immigration controls. Meanwhile, host families are provided with risk-free, cheap childcare. I have explored how these entrenched legal uncertainties manage a deep ambivalence about foreign workers and childcare in Australia. An official au pair scheme (as advocated for by au pair agencies in Australia) could ameliorate some of these most extreme insecurities but only if it foregrounds au pairs' employment rights.

\section{References}

B. Anderson (2009) '“What's in a Name? Immigration Controls and Subjectivities: The Case of Au Pair and Domestic Worker Visa Holders in the UK', Subjectivity, 29, 407-24.

B. Anderson, M. Ruhs, B. Rogaly and S. Spencer (2006) Fair Enough? Central and East European Migrants in Low Wage Employment in the UK (York: Joseph Rowntree Foundation).

J. Baxter (2005) 'White Australians and Male Breadwinners: The Role of Employment and Immigration Policies in Shaping Domestic Labour Patterns in Australia' in S. Huang, B. S. A. Yeoh and N. A. Rahman (eds.) Asian Women as Transnational Domestic Workers (Singapore: Marshall Cavendish Academic) 380-94.

M. Bittman (1995) 'Recent Changes in Unpaid Work' (Occasional Paper, Australian Bureau of Statistics cat no 4154.0).

M. Bittman, G. Matheson and G. Meagher (1999) 'The Changing Boundary Between Home and Market: Australian Trends in Outsourcing Domestic Labour', Work Employment Society, 13, 24973. 
P. Callister, L. Tortell and J. Williams (2009) ‘Paid Domestic Work: A Private Matter or a Public Policy Issue?' (Institute of Policy Studies, Victoria University of Wellington, New Zealand, Working Paper 09/02).

CAPAA (2014) Cultural Au Pair Association of Australia, 'Future Demand for Au Pairs: An Industry Perspective', Submission No 238 to the Productivity Commission Inquiry into Childcare and Early Childhood Learning.

J. A. Chuang (2013) 'The US Au Pair Program: Labor Exploitation and the Myth of Cultural Exchange', Harvard Journal of Law E Gender, 36, 269-343.

S. Collins (2013) 'Perfect Match: Au Pairs and Parents Link up on Internet', Sydney Morning Herald, 6 April.

R. Cox (2007) 'The Au Pair Body: Sex Object, Sister or Student?', European Journal of Women's Studies, 14, 281-96.

R. Cox (2012) 'Gendered Work and Migration Regimes' in R. A. Sollund (ed.) Transnational Migration, Gender and Rights (Advances in Ecopolitics, Volume 10) (Emerald Group Publishing Limited) 33-52.

R. Cox and R. Narula (2003) 'Playing Happy Families: Rules, Relationships in Au Pair Employing Households in London, England', Gender, Place and Culture, 10(4), 333-44.

M. Crock and L. Berg (2011) Immigration, Refugees and Forced Migration: Law, Policy and Practice in Australia (Sydney: Federation Press).

Cudgegong Soaring Pty Ltd v Harris (1996) 13 NSWCCR 92.

DIAC (2012) Department of Immigration and Citizenship, Working Holiday Maker Visa Program Report: 31 December 2012 (Canberra: Cth of Australia).

P. Hamilton and B. W. Higman (2003) 'Servants of Empire: The British Training of Domestics for Australia, 1926-31', Social History, 28(1), 67-82.

G. Harding and E. Webster (2001) The Working Holiday Maker Scheme and the Australian Labour Market (Melbourne: University of Melbourne Institute of Applied Economic and Social Research).

B. W. Higman (2002) Domestic Service in Australia (Melbourne: Melbourne University Press).

A. L. Howe (2009) 'Migrant Care Workers or Migrants Working in Long-Term Care? A Review of Australian Experience', Journal of Aging and Social Policy, 21(4), 374-92.

S. Howells (2011) Report of the 2010 Review of the Migration Amendment (Employer Sanctions) Act 2007 (Canberra: Commonwealth of Australia). 
G. Hugo (2009) 'Care Worker Migration, Australia and Development', Population Space Place, 15(2), 189-203.

L. W. Isaksen (2010) (ed) Global Care Work: Gender and Migration in the Nordic Countries (Lund, Sweden: Nordic Academic Press).

JSCM (1996) Joint Standing Committee on Migration, Transcript, Hearing of Inquiry into Working Holiday Visas, Parliament of Australia, 2 September 1996.

JSCM (1997) Joint Standing Committee on Migration, Working Holiday Makers: More than Just Tourists, Parliament of Australia.

C. Marriner (2013) ‘Call for Au Pair Visa to Tackle Shortage’, Sydney Morning Herald, 3 March.

L. Mellini, C. Yodanis and A. Godenzi (2007) “"On Par”? The Role of the Au Pair in Switzerland and France', European Societies, 9(1), 45-64.

Migration Act 1958 (Cth).

Migration Regulations 1994 (Cth).

D. Miletic (2014) 'Call for Special Working Holiday Visas and Subsidies for Au Pairs', Sydney Morning Herald, 2 February.

Productivity Commission (2013) Terms of Reference Childcare and Early Childhood Learning Inquiry, 22 November.

A. Reilly (2012) 'Protecting Vulnerable Migrant Workers: The Case of International Students', Australian Journal of Labour Law, 25, 181-208.

R. Sollund (2010) 'Regarding Au Pairs in the Norwegian Welfare State', European Journal of Women's Studies, 17(2), 143-160.

A. Stewart and R. Owens (2013) The Nature, Prevalence and Regulation of Unpaid Work Experience, Internships and Trial Periods in Australia: Experience or Exploitation? (Adelaide, Australia: University of Adelaide).

A. Summers (2003) The End of Equality: Work, Babies and Women's Choices in 21 ${ }^{\text {st }}$ Century Australia (Sydney: Random House Australia)

Y. Tan and L. H. Lester (2012) 'Labour Market and Economic Impacts of International Working Holiday Temporary Migrants to Australia', Population, Space and Place, 18(3), 359-83.

Y. Tan, S. Richardson, L. Lester, T. Bai and L. Sun (2009) Evaluation of Australia's Working Holiday Maker Program (Canberra: Department of Immigration and Citizenship). 
B, Westcott (2013) 'Desperately Seeking Longer Stay for Extra Au Pair of Hands', The Australian, 20 July.

C. Yodanis and S. R. Lauer (2005) 'Foreign Visitor, Exchange Student, or Family Member? A Study of Au Pair Policies in the United States, United Kingdom and Australia', International Journal of Sociology and Social Policy, 25(9), 41-64.

i 19 countries are specified for the subclass 417 Working Holiday visa: Belgium, Canada, Cyprus, Denmark, Estonia, Finland, France, Germany, Hong Kong, Ireland, Italy, Japan, South Korea, Malta, the Netherlands, Norway, Sweden, Taiwan and the United Kingdom. Nine are specified for the subclass 462 Work and Holiday visa: Thailand, Chile, Turkey, United States of America, Malaysia, Indonesia, Bangladesh, Argentina and Uruguay. For fuller discussion of the scheme see Crock and Berg 2011, 285-6. ii Condition 8547 attaches to each visa: Migration Regulations sch 2, cll 417.611 and 462.611.

iii Migration Regulations sch 2, cl 417.211(5). The list of regional areas presently covers all of Australia excluding the Australian Capital Territory, Sydney, Wollongong, Newcastle, the Central Coast, Melbourne, Brisbane, the Gold Coast and Perth.

iv See, eg, http://www.aupairinaustralia.com.au/information-for-host-families/placement-process.html; http://www.aupairnetwork.com.au/families.php.

v See eg http://www.aupairnetwork.com.au/families.php.

vi One agency provides the following note on their website: 'TheBestAupair recommends the host family contact the ATO to discuss whether or not they are obliged to withhold tax from an au pair's pocket money. If they are required to do so, the au pair will need to apply for a tax file number and depending on which state the family lives in, they may also be required to pay worker's compensation insurance'. See http://www.thebestaupair.com/en/information-support/a-to-z-index/v/visa-regulations/au-pairin-australia.aspx.

vii 'Domestic' work is excluded from protections under the Industrial Relations Act 1979 (WA) s 7(1), Fair Work Act 1994 (SA) s 6 and Fair Work (General) Regulations 2009 (SA) reg 5. 